\title{
Biological Morphology and Ethano-Pharmocological Importance of Calotropis Species-A Review
}

\author{
Navdeep Ranjan*, Sushil Kumar Singh and Chandrawati Kumari \\ Department of Biotechnology, A.N. College, Patna, (Magadh University), Bihar, India \\ *Corresponding author
}

\begin{tabular}{|c|c|}
\hline & A B S T R A C T \\
\hline $\begin{array}{l}\text { Ke y w o r d s } \\
\text { Calotropis, } \\
\text { Ethano- } \\
\text { pharmacology, } \\
\text { Morphology. }\end{array}$ & $\begin{array}{l}\text { Calotropis a medicinal plant of family Asclepiadaceae has been utilized in Ayurveda, } \\
\text { Unani, Siddha and many other traditional systems to cure diseases. There are two common } \\
\text { species of Calotropis viz. Calotropis gigantean (Linn.) R.Br. and Calotropis procera } \\
\text { (Ait.) R.Br. Calotropis gigantea called Swetarka and Calotropis procera called Raktarka. } \\
\text { Secondary metabolites of Calotropis have well known pharmaceutical and therapeutic } \\
\text { applications. Chemical constituents of plants such as alkoloids, steroid, terpenoids, resin, }\end{array}$ \\
\hline Article Info & $\begin{array}{l}\text { glycosides, carbohydrates, etc are reported in Ayurvedic literature. This present review } \\
\text { enumerates the morphology and ethno pharmacology utilization of } C \text {. procera and } C \text {. }\end{array}$ \\
\hline $\begin{array}{l}\text { Accepted: } \\
\text { 15 March } 2017 \\
\text { Available Online: } \\
10 \text { April } 2017\end{array}$ & $\begin{array}{l}\text { gigantea for the treatment of various human ailments. This plant has been known to } \\
\text { possesses antibacterial activity, anti- inflammatory activity, schizontocidal activity, anti } \\
\text { larvicidal activity, antioxidant activity, skin disease, jaundice, leucoderma, eczema, ulcer, } \\
\text { piles, dysentery, dropsy, ring worm, removing thorn from body, elephantiasis and leprosy } \\
\text { and other miscellaneous activities. }\end{array}$ \\
\hline
\end{tabular}

\section{Introduction}

As stated by Acharya Charak $\left(6^{\text {th }}\right.$ century to $2^{\text {nd }}$ century) that there is nothing in this world which cannot be used as medicine after proper purification, formulation and given in appropriate doses. A poison after proper purification if given in appropriate doses, can act as a medicine. Calotropis also called as Arka, is an example of plant having both therapeutic and toxicological properties. According to Ayurveda, action of a drug depends upon seven factors viz. dravya, rasa, guna, veerya, vipaka, prabhav and karma while active ingredient present in body is solely responsible for its effect and side effect according to modern science, this is the basic difference in the pharmacological principle of both the sciences. Modern science uses the single active principle in the form of medicine while Ayurveda advocate use of effective part of the plant as a whole.

Medicinal plants are used from the ancient time to cure the diseases and it is the sources of different drugs formulation in all systems of medicine. The allopathic, Ayurvedic and Unani medicines were obtained by plant resources, the presently available drugs, either directly in the extract form or in the modified synthetic form. Naturally, plants have the ability to synthesize natural products which are beneficial for us known as phytoconstituents that are used to perform biological functions. Calotropis species is used in several traditional medicine and 
folklore systems to cure various ailments as reported in the Hindu literature. It is widely used in the Indian traditional medicinal system as well as in Arabic, Unani and Sudanese systems. It is also reported widely in various folklore preparations and ethnomedicines, the plant posses many secondary metabolites. The secondary metabolites are biologically active and structurally unique compounds which may be useful for generation of new medicines. Secondary metabolites of Calotropis have well known pharmaceutical and therapeutic applications. Chemical constituents of plants such as Alkoloids, Steroid, Terpenoids, Resin, Glycosides, Carbohydrates, Aluminum, Iron, Magnesium, and Sodium are reported in Ayurvedic literature. These chemicals are reported to be Analgesic, Resilient, Antiinflammatory, Schizontocidal Activity (P. Sharma et al., 1999), Emetic, Expectorant, Stomachic, Digestive, Laxative and Depurative. Further, these phytoconstituents are also reported potentially active for the treatment of several diseases such as Skin disease, Jaundice (Jan et al., 2009), leucoderma, eczema, ulcer, piles, dysentery (Khan et al., 2009), dropsy, ring worm (Kuta, 2008) and removing thorn from body (Rai et al., (2000). Calotrois root bark is very largely used as a treatment for elephantiasis and leprosy. The latex is as potent as standard anti-inflammatory drug phenylbutazone (PBZ) in inhibiting inflammatory response induced by various inflammagens in acute and chronic models of inflammation.

Preferred Scientific Name: Calotropis procera

Calotropis gigentia

Preferred Common Name: $\quad$ Akwan, Arka, Madar in India

Systematic classification

Table.1 Systematic classification of Calotropis procera given by three taxonomists

\begin{tabular}{|l|l|l|l|}
\hline Classification & Bentham and Hooker & Engler and Prantl & Hutchinson \\
\hline Kingdom & Plantae & Plantae & Plantae \\
\hline Class & Dicotyledones & Dicotyledones & Dicotyledones \\
\hline Division & Gamopetalae & Sympetalae & Lignosae \\
\hline Order & Gentianales & Asclepiadaceae & Asclepiadaceae \\
\hline Family & Asclepiadaceae & Asclepiadaceae & Asclepiadaceae \\
\hline Genus & Calotropis & Calotropis & Calotropis \\
\hline Species & Procera & Procera & procera \\
\hline
\end{tabular}

Table.2 Systematic classification of Calotropis gigentea given by three taxonomists

\begin{tabular}{|l|l|l|l|}
\hline Classification & Bentham and Hooker & Engler and Prantl & Hutchinson \\
\hline Kingdom & Plantae & Plantae & Plantae \\
\hline Class & Dicotyledones & Dicotyledones & Dicotyledones \\
\hline Division & Gamopetalae & Sympetalae & Lignosae \\
\hline Order & Gentianales & Asclepiadaceae & Asclepiadaceae \\
\hline Family & Asclepiadaceae & Asclepiadaceae & Asclepiadaceae \\
\hline Genus & Calotropis & Calotropis & Calotropis \\
\hline Species & Gigentia & Gigentia & gigentia \\
\hline
\end{tabular}


Table.3 International name

\begin{tabular}{|l|l|}
\hline England & $\begin{array}{l}\text { Calotrope, calotropis, dead Sea fruit, desert wick, giant milkweed, swallow-wort, } \\
\text { mudar fibre, rubber bush, rubber tree, sodom apple. }\end{array}$ \\
\hline Arabic & Dead sea plant, debaj, usher, oshar, kisher \\
\hline Malaysia & Remiga, rembega, kemengu \\
\hline German & Wahre mudarpflanzer, gomeiner \\
\hline Philippines & Kapal-kapal (Tagalog) \\
\hline Spanish & Bomba, algodón extranjero, cazuela \\
\hline Indonesia & Bidhuri (Sundanese, Madurese), sidaguri (Javanese), rubik (Aceh) \\
\hline Chinese & Bai hua niu jiao gua \\
\hline Somali & Boah, bo'ah \\
\hline French & Faux arbre de soie, mercure vegetal \\
\hline Turkish & Ipekag \\
\hline Thailand & Po thuean, paan thuean (northern), rak (central). \\
\hline Laos & Kok may, dok kap, dok hak \\
\hline Persian & Kharak \\
\hline Vietnam & B[oot]ng b[oot]ng, l[as] hen, nam t[it]b[at] \\
\hline Nigeria & Tumfafia \\
\hline Pakistan & Ak \\
\hline
\end{tabular}

Table.4 National name

\begin{tabular}{|l|l|}
\hline Sanskrit & Arka, Ganarupa, Mandara,Vasuka, Svetapushpa, Sadapushpa, Alarka, Pratapass \\
\hline Hindi & Aak, Madar \\
\hline Bengali & Aakna \\
\hline Urdu & Madar, aak \\
\hline Punjabi & AK \\
\hline Marathi & Rui, mandara \\
\hline Kannada & Ekka \\
\hline Tamil & Erukku \\
\hline Telugu & Jilledi Puvvu \\
\hline Malyalam & Neela Eukku \\
\hline
\end{tabular}

Table.5 National distribution

\begin{tabular}{|l|l|l|l|l|}
\hline Country & Ditribution & Origin & Invasive & Natural \\
\hline India & Present & Native & Invasive & Natural \\
\hline
\end{tabular}

Table.6 International distribution

\begin{tabular}{|l|l|l|l|l|}
\hline Country & Distribution & Origin & Invasive & Natural \\
\hline Afghanistan & Present & Native & Invasive & Natural \\
\hline China & Present & Introduced & Invasive & Natural \\
\hline USA & Present & Introduced & Invasive & Natural \\
\hline Bangladesh & Present & Native & Invasive & Natural \\
\hline Mexico & Present & Introduced & Invasive & Natural \\
\hline Brazil & Present & Introduced & Invasive & Natural \\
\hline Pakistan & Present & Native & Invasive & Natural \\
\hline
\end{tabular}


Table.7 Etano- pharmacological importance of Calotropis species

\begin{tabular}{|c|c|c|}
\hline Sl.No. & Pharmacological Importance & Plant parts used \\
\hline 1. & Antibacterial activity & Leaf, Flower, Root or Whole plant \\
\hline 2. & Antiviral activity & Leaf, or Whole plant \\
\hline 3. & Antifertility and emmenagogue & Leaf, Flower, Root, Latex OR Whole plant \\
\hline 4. & Anti-inflammatory activity & Leaf, Latex \\
\hline 5. & Anti tumor activity & Leaf, Flower, Root, Latex or Whole plant \\
\hline 6. & Anti-diarrheal and anti dyssentry activities & Leaf, Flower, Root, \\
\hline 7. & Anti cancer activity & Leaf, Flower, Root, \\
\hline 8. & Asthma & Flower \\
\hline 9. & Anxiety and pain & Leaf, Flower, Root, \\
\hline 10. & Abortifacient & Leaf, Flower, Latex \\
\hline 11. & Analgesic and Antinociceptive activity & Leaf, Root, \\
\hline 12. & Cytotoxic activity & Leaf, Flower, Root, \\
\hline 13. & CNS activity & Leaf \\
\hline 14. & Cold & Leaf \\
\hline 15. & Cytostatic activity & Flower, Root, \\
\hline 16. & Dyspepsia & Leaf, Flower, Root, Latex \\
\hline 17. & Diabetes mellitus & Leaf, Flower, Root, \\
\hline 18. & Eczema & ,Latex \\
\hline 19. & Expectorant & Leaf, Flower \\
\hline 20. & Elephantiasis of the legs and scrotum & Leaf, Flower, Root, \\
\hline 21. & Fever & Leaf, Flower, Root, Latex OR Whole plant \\
\hline 22. & Free radical Scavenging activity & Leaf, Flower, Root, Latex OR Whole plant \\
\hline 23. & Fibrinolytic activities & Leaf, Flower, Root, Latex OR Whole plant \\
\hline 24. & Healing the ulcers and blotches & Leaf, Flower, Latex OR \\
\hline 25. & Indigestion & Leaf \\
\hline 26. & Jaundice & Leaf, \\
\hline 27. & Leprosy & Latex \\
\hline 28. & Liver injuries as well as on oxidative stress & Leaf, Flower, Root, \\
\hline 29. & Mental disorders & Flower, \\
\hline 30. & Piles & Latex \\
\hline 31. & Pregnancy interceptive activity & Leaf, Flower, Root, Latex or Whole plant \\
\hline 32. & Removing anemia & Leaf, Flower, Root, Latex or Whole plant \\
\hline 33. & Rheumatism & Leaf \\
\hline 34. & Ringworm of the scalp & Leaf, Flower, Root, Latex \\
\hline 35. & Secondary syphilis & Leaf, Flower, Latex \\
\hline 36. & Skin diseases & Leaf, Flower, Root, Latex \\
\hline 37. & TB & Leaf, Flower, Root, \\
\hline 38. & Uterus stimulant & Leaf, Flower, \\
\hline 39. & Vermicidal activity & Leaf, Flower, Root, Latex \\
\hline 40. & Worms & Leaf, Flower, Root, \\
\hline 41. & Wound healing & Leaf, Flower, Root, \\
\hline
\end{tabular}

(sources) 


\section{Distribution}

Calotropis is native to tropical Africa and Asia and introduced to the Southern United States and Brazil (Crothers et al., 1998). It is naturalized in Australia, many Pacific islands, Mexico, Central and South America and the Caribbean islands.

The Fresh leaves are used in treatment of Rheumatoid, Arthritis and Healing of wounds (Patil et al., 2009). The pungent latex extracted from the leaf and flowers of $C$. procera is processed and used in the commercial preparation of eye tonic (Vohra, 2004; Henrich et al., 2004; Gurib-Fakim, 2005; Bruneton, 1999).

\section{Morphology}

Calotropis species is a shrub with thick twisted branches, the young ones bluntly quadrangular, bark ash colored, covered with a minute white woolly down (Ahirwar et al., 2007). The species can be differentiated by the floral characterstics. Calotropis gigantea bears corolla lobes which are spreading, uniformly coloured, pure lavender to white, coronal scales narrow truncate shorter than the staminal column with pubescent back, apex entire. Whereas the corolla lobes of Calotropis procera are erect while pink or purple spotted on the corolla lobes, corona scales equal or longer than the staminal column, glaburous on back apex bifid, auricles wanting (Raman Sehgal et al., 2005).

\section{Habit}

An upright shrub or small tree usually growing 1-4 m tall.

\section{Habitat}

It is drought-resistant, salt-tolerant species, grows in poor soils, found along roadsides, railway tracts watercourses, river side and coastal dunes, and is often prevalent in disturbed areas. Found mostly in semi-arid and arid inland areas, as well as in the drier parts of tropical and sub-tropical regions.

Somatic chromosomes: $2 n=22$

\section{Karyotypic formulae}

Calotropis procera $\mathrm{Br} .=$

mi6+sm6+sto+to $=2 \mathrm{n}=22$

Calotropis gigantea

$\mathrm{Br} .=\mathrm{mi} 6+\mathrm{sm} 6+$ sto + to $=2 \mathrm{n}=22$

\section{Chromosomal Formulae}

Calotropis procera $\mathrm{Br} .=$ $\mathrm{A} 6+\mathrm{B} 4+\mathrm{C} 6+\mathrm{D} 4+\mathrm{E} 2+\mathrm{Fo}=2 \mathrm{n}=22$

Calotropis gigantea $\mathrm{Br}=\mathrm{A} 2+\mathrm{B}$

$\mathrm{io}+\mathrm{C} 6+\mathrm{Do}+\mathrm{E} 4+\mathrm{Fo}=2 \mathrm{n}=22$

Root: Taproot, approximately 3000-4000 mm deep.

\section{Stems}

Approximately $2000-4000 \mathrm{~mm}$ tall, erect, branched, glabrous, woody below and herbaceous above, tomentose, solid, cylindrical. Branched from the base at times and branched higher up, Waxy, Copious milky sap exuded when injured.

\section{Leaves}

Oval, broad and flat in opposite pairs, thick and hairless apart from a basal tuft, leaves are arranged at higher angles. Waxy Grey-green to blue green with indented bases. Nonepetiole. Blade - Thick, egg shaped. Approx 50- $150 \mathrm{~mm}$ long x 40-100 mm wide, tip pointed. Notched at the base where it clasps the stem. Stiff tuft of hairs at the base of the midrib. 


\section{Inflorescence}

Cymose, umbellate cyme, dense, multiflowered, umbellate, peducled, cymes, arising from the nodes and appearing axillary or terminal.

\section{Flower head}

In groups (umbels) of up to 15 flowers in the upper leaf axils, outer flowers develop first and inner ones don't develop fully.

\section{Flowers}

Approx $25 \mathrm{~mm}$ wide, scented and white with a deep purple blotch at the base of each petal, Waxy texture, Bracts - Deep purple bracts between the petals and stamens, (5) lobed, 20-30 mm wide, Scented. No milky sap. Petals - Deep purple bracts between the petals and stamens, tubular, five (5) lobed. 20-30 mm wide. Stamens - five (5) united with the stigma to form gynostegium, each stamen is represented by two pollinia with their retinaculae. Anther is bilocular and with a hyaline outgrowth of the connective that covers the stigmatic disc at the periphery; appendaged. It appendages are apical. Unisexual flowers absent.

\section{Pollination}

Each anther sac contains a pollinium. There are five pollinaria, each consisting of paired pollinia from adjacent anthers jointed by translator arms to a corpusculum located just above the slit or opening of the stigmatic chamber.

The stigmatic chambers are beaklike, due to raised anther flaps (wings). Anther flaps are hard, straight and enclose the stigmatic chamber tightly. Each pollinium is a flat wing-like body, narrow at its base close to the translator and wide at the apex. It has no external appendages and no pellucid margin.

\section{Calyx}

Sepal five (5), Polysepalous, five (5) lobed, shortly united at the base, glabrescent, quincuncial aestivation.

\section{Corolla}

Petals five (5), gamopetalous, five (5) lobed, twisted aestivation, Petals, gamopetalous, pink or whitish with purple spots, lobes spreading, inferior, twisted aestivation.

\section{Androcium}

Stamens five (5), gynandrous, anther dithecous, coherent, Five (5) stamens, filaments connate in a fleshy staminal tube around the ovary, the apex of the staminal tube united with the much-dilated stigmatic head to which the anthers are also coherent, forming the pentagonal gynostegium; anthers short, broad tipped with inflexed membranous flaps, bi-celled, the pollen grains of each cell aglutinated into sac like pollinium; the pollinia of each anther are united together by means of short stalks or caudicles to a distinct dark coloured dot-like structure, the corpusculum, which lies at the angle of the gynostegium, thus forming a translator apparatus.

\section{Gynoecium}

Bicarpellary, apocarpus, styles are united at their apex, peltate stigma with five (5) lateral stigmatic surfaces. Anthers adnate to the stigma forming a gynostegium. 2 carpels (bicarpellary), syncarpous; the pistil free below and fused above; two distinct ovaries end in two styles forming a pentangular stigmatic head to the sides of which the anthers are coherent; ovary superior, unilocular, many ovules, marginal placentation. Placentation axile. Ovules 30 50 per locule ('many'). 


\section{Fruit}

Long and balloon like. Follicle (bladdery pod). Grey-green. 70-125 mm long and almost as wide. Rounded at the base. Tip pointed. Numerous (400- 600) seeds are released when the ripe pod bursts. A simple, fleshy, inflated, subglobose to obliquely ovoid follicle up to $10 \mathrm{~cm}$ or more in diameter.

\section{Seeds}

Brown, Flattened, Tuft of long, white, silky hairs at top. Many, small, flat, obovate, $6 \times 5$ $\mathrm{mm}$, compressed with silky white pappus, 3 $\mathrm{cm}$ or more long, Mainly, broadly ovate, flat tomentose with tuft of silky hairs.

\section{Physiology}

Salt tolerant, root stocks tolerate fire and drought.

\section{Reproduction}

Plants hermaphrodite, plants homostylous. Reproduces usually by seed and sometimes by suckers.

\section{Flowering times}

July to October mainly but can flower at any time of year. Fruit mainly ripens from November to February.

\section{Life cycle}

Seed germinates from October to December with tropical rain and it makes rapid growth in the wet season. Flowers occur in August to October when the plant is probably two years old. Flowers stay open for 10-12 days. Fruit is set from September to November and has many seeds. They ripen from November to February then burst to release seeds. New growth and suckering is stimulated by the break of each season in October to December.

\section{Seed biology and germination}

Prefers to germinate in light conditions and seed germination is inhibited in shaded conditions. Seed normally germinates in favorable conditions. Good germination takes place when temperature alters at 40/20 degrees Celcius and 36/21 degrees Celcius.

\section{Vegetative propagules}

Crowns and roots form suckers. Broken stems may take root and regenerate.

\section{Propagation and management}

The seeds freely float in the air and natural regeneration is very common. Vegetative propagation through stem and root cutting is very useful in large scale multiplication of the superior genotypes. Calotropis has been cultivated in South America and on the Caribbean Islands for the production of fibres at a spacing of $1-1.5 \mathrm{~m}$. When cultivated annualy yields of up to $500 \mathrm{~kg} / \mathrm{ha}$ are expected.

A single harvest per season is preferable to a double or triple harvest; a single harvest would result in a net saving of energy input both on the form and in the processing plant.

It is well suited for intensive energy farming in arid or semi-arid regions where frost is not a limiting factor.

\section{Population dynamics and dispersal}

In 5 years one WA infestation grew from 20ha to over 5000ha. Seeds are spread by wind and water or mud attaching to passing animals and vehicles. Localised spread is from suckering of the roots and crowns and seedling recruitment.

Earthmoving equipment is a major means of spreading rootstocks and seeds. 
Floral formula

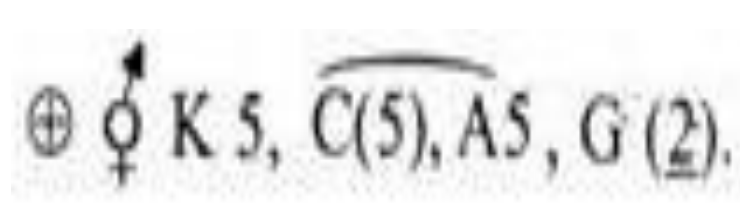

Floral diagram

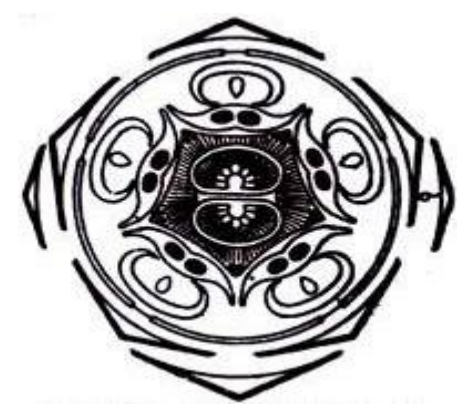

of synthetic compounds are available but due to their environmental pollution and adverse effect on the human body there use is restricted. To find the safe, effective, and environmental friendly agent from a plant source, Calotropis is a plant that may present as effective one. The literature on Calotropis suggests a huge biological potential of this plant. The present study may be useful to provide morphological information with regard to its identification and in accordance to carry out further research on its use in the treatment of various diseases and secondary metabolites will be useful for development of novel drugs to treat many human diseases in the modern era of globalization and intellectual property right regime after proper islotation, purification and formulation.

\section{References}

Ahirwar, D., Ahirwar Bharti, Kharya, M.D. 2007. Influence of Calotropis procera roots on biochemistry of reproductive organs of ovariectomized rats. Indian J. Pharm. Sci., Vol 69, pp. 459-461.

Bruneton, J. 1999. Pharmacognosy, Phytochemistry and Medicinal Plants. Intercept. Ltd. England, U.K.

Gurib-Fakim, A. 2006. Medicinal plants: Traditions of yesterday and drugs of tomorrow. Mol. Aspects of Med., 27: 193.

Heinrich, M., Barnes, J., Gibbons, S., and Williamson, E.M. 2004. Fundamentals of Pharmacog. Phytother., Churchill 
Livingstone, Elsevier Science Ltd., UK.

Jan, G., Khan, M.A. and Gul, F. 2009. Ethnomedicinal plants used against jaundice in Dir Kohistan.Valleys (NWFP), Pakistan, Ethnobot. Leaflets, 13: $1029-41$.

Khan, F.M. 2009. Ethnoveterinary medicinal usage of flora of greater Cholistan Desert Pakistan.

Kuta, F.A. 2008. Antifungal effects of calotropis procera stem back on Epidermophyton, Flocosum and Trichophyton, gypseum. African $J$. Biotechnol., 7(13): 2116-2118.

Patil, S.B., Naikwade, N.S., Kondawar, M.S., Magdum, C.S. and Awale, V.B. 2009. Traditional uses of plants for wound healing in the Sangli District,
Maharashtra, Int. J. Pharm. Tech. Res., 1(3): 876-878.

Sharma, P., J.D. Sharma. 1999. Evaluation of in vitro schizontocidal activity of plant parts of calotropis procera- an ethanobotanical approach, J. Ethnopharmacol., 68: 83-95.

Rai, M.K., Pandey, A.K. and Acharaya, D. 2000. Ethnomedicinal plants used by Gond tribe of Bahanalehi District Chhinwara, M.P. J. Nontimber Forest, 7(3/4): 237-241.

Raman Sehgal and Vijay, L., Kumar. 2005. Calotropis procera Latex-Induced Inflammatory Hyperalgesia-Effect of Antiinflammatory Drugs. Mediators Inflamm., Vol 4, pp. 216-220.

Vohra, R. 2004. Calotropis the medicinal weed. Online medicinal book store, India.

\section{How to cite this article:}

Navdeep Ranjan, Sushil Kumar Singh and Chandrawati Kumari. 2017. Biological Morphology and Ethano - Pharmocological Importance of Calotropis Species- A Review. Int.J.Curr.Microbiol.App.Sci. 6(4): 1640-1648. doi: https://doi.org/10.20546/ijcmas.2017.604.200 